\title{
Phytoprotection
}

\section{Challenges for the Safe Use of Transgenic Arthropod Natural enemies for Pest Management Programs}

\author{
Marjorie A. Hoy
}

Volume 79, numéro 4, 1998

OECD Workshop - Sustainable Pest Management, Safe Utilization of New Organisms in Biological Control. Montréal, Québec, Canada. September 27-30, 1998.

Atelier de l'OCDE - Gestion durable des ennemis des cultures, Utilisation sécuritaire de nouveaux organismes de lutte biologique. Montréal, Québec, Canada. 27-30 Septembre 1998.

URI : https://id.erudit.org/iderudit/706173ar

DOI : https://doi.org/10.7202/706173ar

Aller au sommaire du numéro

Éditeur(s)

Société de protection des plantes du Québec (SPPQ)l

ISSN

0031-9511 (imprimé)

1710-1603 (numérique)

Découvrir la revue

Citer cet article

Hoy, M. A. (1998). Challenges for the Safe Use of Transgenic Arthropod Natural enemies for Pest Management Programs. Phytoprotection, 79(4), 139-143.

https://doi.org/10.7202/706173ar d'utilisation que vous pouvez consulter en ligne. 


\title{
Challenges for the Safe Use of Transgenic Arthropod Natural Enemies for Pest Management Programs
}

\author{
Marjorie A. Hoy \\ Department of Entomology and Nematology, University of Florida, \\ PO Box 110620, Gainesville, Florida 32611-0620 USA
}

\section{INTRODUCTION}

In the coming years we will need more biological control rather than less. The threat of alien invasive pests is accelerating in many regions due to increased international travel and trade. For example, just since 1992 three foreign insect pests (citrus leafminer, Phyllocnistis citrella; citrus psylla, Diaphorina citri; and brown citrus aphid, Toxoptera citricida) have invaded Florida's citrus groves. Because the integrated pest management (IPM) program for citrus in Florida is based on biological control, these newly-introduced pests must be managed in a manner that does not disrupt the effective natural enemies that suppress mites, whiteflies, mealybugs, scales, leafminers, and other arthropods. We are on a "biological control treadmill" in Florida citrus because the introduction of a single new pest that cannot be controlled in a manner compatible with a biologicalcontrol based IPM program threatens to disrupt the entire system.

In the USA, President Clinton set a goal of having the majority of US agriculture under IPM by the year 2000. If new pests are controlled by nontoxic methods (including mating disruption, sterile insect releases), formerly suppressed pests may become apparent. A number of these so-called "secondary pests" may become targets of augmentative or conservation biological control programs. The increased importance of biological control will probably be international in scope as consumers become more concerned about the potential health risks associated with pesticide residues in food and water.

With the introduction of new and stricter legislation (such as the Food Quality Protection Act in the USA) regarding pesticide residues on foods, biological control will become more important than it is today in cotton, corn, wheat, rice, and other row crops. Some pests may be brought under control by the deployment of transgenic crops and this could provide new opportunities for biological control if the transgenic crops are compatible with natural enemies.

\section{BIOLOGICAL CONTROL UNDER SIEGE}

Despite the promise that biological control can reduce pesticide use and their detrimental effects on the environment and human health, classical biological control currently is under attack around the world because of concerns about potential risks to the environment, especially to nontarget insects and plants. This has raised issues that are both useful and disruptive to the use of classical and augmentative biological control. The increased focus on importing host-specific natural enemies is appropriate and should result in improved efficacy as well as fewer effects on nontarget species. Yet, 
as a classical biological control practitioner, I find that these concerns have created problems that can delay programs and make them more expensive. There is concern that the production of transgenic natural enemies will intensify the scrutiny of biological control by regulatory agencies and environmental groups.

\section{TRANSGENIC NATURAL ENEMIES}

Our ability to develop transgenic insects and mites is improving rapidly (Ashburner et al. 1998) and offers the possibility that genetically-improved natural enemies could be developed. However, there are several important research and policy issues to be resolved before such modified natural enemies can be deployed in practical pest management programs (Hoy 1992a,b, 1995).

The development of transgenic arthropods on a routine basis is still very much a developing field (Hoy 1993, Ashburner et al. 1998). Transformation methods are still being improved; relatively few marker genes are available that allow unequivocal identification of transformed insects; few promoters and other regulatory sequences are available to allow transgenes to be transcribed in the appropriate amounts in the appropriate tissues at the appropriate time. Few genes have been cloned that could be used to improve the efficacy of arthropod natural enemies. It could be some years before transgenic natural enemies with useful (not just marker) genes are produced for practical pest management programs.

1) Will funds become available for developing transgenic arthropod natural enemies? Most classical biological control programs are carried out by public sector agencies, which often lack sufficient funds to develop transgenic natural enemies. I know of no commercial entity interested in developing transgenic arthropod natural enemies because the time required to deploy the agent in the field is perceived to be too long, the payoffs uncertain, and the regulatory and risk assessment issues remain unresolved. Most companies involved in mass production of natural enemies for augmentative releases (and one can expect transgenic natural enemies would be particularly useful in augmentative biological control) are small and have very limited research budgets that would preclude them from investing in such long term research.

2) Are transgenic natural enemies inherently more risky than non-modified natural enemies? It is not a new question: the debate about risk in transgenic crop plants serves as a model with two divergent opinions based on differing assumptions: one group considers that transgenic technology is new and unique and that transgenic organisms need to be considered very carefully no matter the genetic change (transgenic organisms are inherently risky). The other group would argue that transgenic technology is not significantly different from conventional genetic manipulation. This group argues that regulations and evaluation should focus on specific traits that may be related to risk rather than on the specific genetic manipulation method.

3) What kind of risk assessment and regulation should be imposed on transgenic arthropod natural enemies?

At present, in the USA, short term releases of transgenic arthropods are regulated by the USDA-APHIS, as described in detail at the following website: (http://www.aphis.usda.gov:80/ bbep/bp/arthropod/\#tgenadoc). Assessments are based on the principles outlined in Table 1 . The applicant to the USDA-APHIS is expected to demonstrate how the transgenic arthropod will be contained in the release plot and retrieved (or mitigated should it escape). The only transgenic arthropod released to date is a natural enemy, a predatory phytoseiid with a low rate of dispersal (Hoy et al. 1997, McDermott and Hoy 1997). 
Table 1. Some issues to resolve relating to risks of releasing transgenicarthropods into experimental field plots

A. Attributes of the Unmodified Organism

- What is the origin of the transgenic organism (indigenous or nonindigenous) in the accessible environment?

- What is the arthropod's trophic level and host range?

- What other ecological relationships does it have?

- How easy is it to monitor and control?

- How does it survive during periods of environmental stress?

- What is the potential for gene exchange with other populations?

- Is the arthropod involved in basic ecosystem processes?

B. Attributes of the Genetic Alteration

- What is the intent of the genetic alteration?

- What is the nature and function of the genetic alteration?

- How well characterized is the genetic modification?

- How stable is the genetic alteration?

C. Phenotype of Modified Organism Compared to Unmodified Organism

- What is the host/prey range?

- How fit and effective is the transgenic strain?

- What is the expression level of the trait?

- Has the alteration changed the organism's susceptibility to control by natural or artificial means?

- What are the environmental limits to growth or reproduction (habitat, microhabitat)?

- How similar is the transgenic strain being tested to phenotypes

- previously evaluated in field tests?

D. Attributes of the Accessible Environment

- Describe the accessible environment, whether there are alternate hosts or prey, wild relatives within dispersal capability of the organisms, and the relationship of the site to the potential geographic range of the transgenic arthropod strain.

- Are there endangered/threatened species present that could be affected?

- Are there vectors or agents of indirect dissemination present in theenvironment?

- Do the test conditions provide a realistic simulation to nature?

- How effective are the monitoring and mitigation plans?

Modified from a discussion held at a conference on "Risks of Releasing Transgenic Arthropod Natural Enemies", held November 13-16, 1993 in Gainesville, Florida (Hoy 1995).

However, application may soon be made to release the first pest insect in the USA, a sterile transgenic pink bollworms containing a marker gene (green fluorescent protein) as part of a sterile insect release program. No transgenic arthropod has been released permanently into the environment and there are no guidelines as to what data or assessments would be required to allow such releases.

Extensive efforts are being made to develop transgenic insects (or their symbionts) that are vectors of human or animal diseases. For example, many laboratories are attempting to develop mosquitoes unable to vector malaria. Transformation of gut symbionts of Chagas' disease vectors has been achieved and field tri- als may be conducted in Guatemala to determine if transmission of the pathogen can be reduced. Risk assessments will have to involve both ecological risks and human health and ethical issues.

A crucial question is: How can transgenic arthropod natural enemies be evaluated for risk in short term releases in a realistic manner when they have a higher dispersal ability than do transgenic plants and microorganisms? How can these natural enemies be contained effectively in the release site, yet be evaluated in an appropriate manner?

Because augmentative releases can be commercialized, these natural enemies could be genetically modified 
using recombinant DNA methods and the costs recovered from consumers. What regulations and risk issues should govern private sector organizations and who should enforce them?

4) The issue of what level of risk is acceptable in biological control has to be resolved (Samways 1997). How do we measure costs, benefits, and risk? What assumptions are made? I don't think that scientists alone can (or should) make these decisions.

\section{RESEARCH NEEDS}

1) Transformation methods, useful genes, and appropriate promoters must be developed for arthropod natural enemies. Molecular methods used to insert transgenes into the chromosome of an insect may not be universally suitable for transforming diverse species; specific methods may have to be developed for each group. Millions of (US) dollars have been spent to identify useful genes for transforming mosquitoes or other vectors of human disease, but almost nothing has been invested to identify genes to improve the effectiveness of arthropod natural enemies. The genes that being identifed in the Drosophila Genome Project may provide an entre to useful genes in the genomes of arthropod natural enemies, but almost no effort is being devoted to this.

2) Horizontal gene transfer of inserted transgenes is a potential risk for any transgenic organism. We know that horizontal gene transfer is a natural evolutionary force and that it is rare, occurring on an "evolutionary time scale". What level of risk can we tolerate? What mechanisms allow horizontal gene transfer? Much research needs to be conducted on the risks of horizontal gene transfer, but such research is very difficult and expensive. Some even argue that we cannot study horizontal gene transfer in laboratory experiments because it is so rare. This research should, however, be a high priority.
3) Releases of transgenic arthropod natural enemies will be made with the assumption that they will retain their expected host or prey preferences and climatic tolerances. Each transgenic population will have to be evaluated under laboratory conditions to confirm that it remains host/ prey specific and that we can predict its geographic range after its release. What laboratory tests and models are sufficient to predict this?

4) Is it possible to develop "crippled" transgenic arthropod natural enemies that are unable to permanently establish in the environment (perhaps because they lack the ability to diapause or otherwise cannot tolerate climatic conditions throughout the year)? Such organisms may be useful for augmentative biological control and would have the added advantage that the commercial entity could sell the new strain each growing season. The ability to produce effective natural enemies that are unable to multiply or persist in the environment will require research to identify or clone suitable genes.

5) The mass production and deployment of transgenic natural enemies will create problems already encountered in the mass rearing of nonmodified natural enemies-loss of genetic variability through inbreeding and genetic bottlenecks, inadvertent selection for laboratory adaptation, and the failure of artificial rearing conditions to allow healthy and fit individuals to develop. Research aimed at improving rearing methods for natural enemies will provide benefits broadly to biological control.

6) The mass production and deployment of transgenic natural enemies in IPM programs potentially might have undesirable ecosystem effects:

- Their extensive use could result in loss of genetic diversity of endemic natural enemy populations;

- A lack of host or prey specificity could affect threatened and endangered nontarget species;

- There is a slight but unknown degree of risk that a host shift to a 
nontarget species could occur. (The genetic basis of host specificity in arthropod natural enemies is largely unknown.)

7) While transgenic arthropod natural enemies are being developed and evaluated in the laboratory for risk, they could escape accidentally. At present no uniform guidelines exist as to how to contain transgenic arthropods until they have been cleared by appropriate regulatory authorities for release. Containment procedures and guidelines were proposed by Hoy et al. (1997) but have not been widely discussed or adopted. It is urgent that we adopt consistent procedures and guidelines so that "every release is a planned release."

\section{RECOMMENDATIONS}

1) Evaluate methods used to deploy transgenic arthropod natural enemies (mass rearing techniques, artificial diets, quality control methods, population dynamics models) before the project begins. Bring ecologists and population geneticists, as well as IPM specialists, into the initial planning of the program so that production and deployment methods are known to be feasible and can be developed in a timely manner (Hoy 1995).

2) Consider whether it makes sense to develop transgenic natural enemies, especially if naturally-occurring biotypes or species can be identified that can do the job (Hoy 1992, 1995). Compare relative costs, benefits, and risks.

3) Develop international containment and risk evaluation guidelines because arthropod natural enemies can disperse rapidly over long distances.

\section{SELECTED REFERENCES}

Ashburner, M., M. A. Hoy and J. Peloquin. 1998. Transformation of arthropods-research needs and long term prospects. Insect Molecular Biology 7(3): 201-213.

Hoy, M. A. 1992a. Criteria for release of genetically-improved phytoseiids: an examination of the risks associated with release of biological control agents. Exp. Appl. Acarol. 14: 393-416.

Hoy, M. A. 1992b. Commentary: Biological control of arthropods: genetic engineering and environmental risks. Biological Control 2: 166-170.

Hoy, M. A. 1993. Transgenic beneficial arthropods for pest management programs: an assessment of their practicality and risks. Pp. 357-369. In: Pest Management: Biologically Based Technologies. R. D. Lumsden and J. L.

Vaughn, Eds., Amer. Chem. Soc. Conf. Proc. Series., Washington, DC. Hoy, M. A. 1995. Impact of risk analyses on pest management programs employing transgenic arthropods. Parasitology Today 11(6):229-232.

Hoy, M. A., R. D. Gaskalla, J. L. Capinera and C. Keierleber. 1997. Forum: Laboratory containment of transgenic arthropods. Amer. Entomol.43(4): 206-209, 255-256.

McDermott, G. J. and M. A. Hoy. 1997. Persistence and containment of Metaseiulus occidentalis (Acari: Phytoseiidae) in Florida: risk assessment for possible releases of transgenic strains. Florida Entomologist 80: 42-53.

Samways, M. J. 1997. Classical biological control and biodiversity conservation: what risks are we prepared to accept? Biodiversity and Conservation 6: 13091316. 